\title{
Changes in Glomerular Hemodynamic Response to Angiotensin II after Subacute Renal Denervation in Rats
}

\author{
B. J. Tucker, C. A. Mundy, A. R. Maciejewski, M. P. Printz, M. G. Ziegler, J. C. Pelayo, and R. C. Blantz \\ University of California, San Diego School of Medicine, La Jolla, California 92093; and \\ Veterans Administration Medical Center, San Diego, California 92161
}

\begin{abstract}
We examined the changes in glomerular hemodynamics produced by angiotensin II (AII) in both normal Munich-Wistar rats and rats which were unilaterally renal denervated (measured kidney) 4-6 d prior to the measurement periods. Measurements of glomerular dynamics were performed in a control period after plasma volume expansion and during infusion of $11 \mathrm{ng} \cdot 100 \mathrm{~g}$ body $\mathrm{wt}^{-1} \cdot \mathrm{min}^{-1}$ of AII. The glomerular hydrostatic pressure gradient increased from $38 \pm 1$ to $49 \pm 1 \mathrm{mmHg}$ in denervated rats compared with a lesser response in controls (from $39 \pm 1$ to $45 \pm 1 \mathrm{mmHg}$, $P<0.05)$. Single nephron plasma flow decreased from $213 \pm 17$ to $87 \pm 4 \mathrm{nl} \cdot \mathrm{min}^{-1} \cdot \mathrm{g}$ kidney wt $(\mathrm{KW})^{-1}$ in denervated kidneys versus a more modest decrease in control kidneys (from $161 \pm 9$ to $102 \pm 5 \mathrm{nl} \cdot \mathrm{min} \cdot \mathrm{gKW}^{-1}$ ). These changes were due to a greater increase in both afferent and efferent arteriolar resistance after AII infusion in denervated compared with control kidneys. Glomerular AII receptor maximum binding was 1,196 $\pm 267 \mathrm{fmol} /$ mg protein in denervated kidneys compared with $612 \pm 89 \mathrm{fmol} /$ mg protein $(P<0.01)$ in controls with no change in receptor affinity. We conclude the subacute unilateral renal denervation (a) results in renal vasodilation, (b) denervation magnifies the vasoconstrictive effect of AII infusion on glomerular hemodynamics, and (c) the observed increased response to AII after denervation is associated with increases in glomerular AII receptors.
\end{abstract}

\section{Introduction}

Studies performed by our laboratory $(1,2)$ and others (3-7) have demonstrated a renal vasoconstrictor response to angiotensin II (AII) ${ }^{1}$ infusion resulting in decreases in renal blood flow and nephron filtration rate as well as a reduction in the glomerular ultrafiltration coefficient. A large amount of investigative effort has been expended in delineating the role of the renin-angiotensin system in the control of glomerular ultrafiltration. Research has revealed a specific interaction between renin release and sym-

Portions of the studies were presented at the annual meeting of the American Federation for Clinical Research, Washington, DC, May 1984. Address reprint requests to Dr. Blantz, VA Medical Center, $3350 \mathrm{La}$ Jolla Village Drive, San Diego, CA 92161.

Received for publication 11 March 1985 and in revised form 18 April 1986.

1. Abbreviations used in this paper: AII, angiotensin II; BW, body weight; DNX, unilaterally denervated (rat); KW, kidney weight; see Glossary for other abbreviations.

J. Clin. Invest.

(c) The American Society for Clinical Investigation, Inc. 0021-9738/86/09/0680/09 \$1.00

Volume 78, September 1986, 680-688 pathetic nerve activity in which renin release is mediated, in part, by adrenergic activity to the kidney (8-10). Studies from this laboratory have also shown that the many effects of renal nerve stimulation can be greatly diminished by inhibitors of $\mathrm{AI}$ to AII converting enzyme or by AII receptor antagonists (11). Data have also been provided that suggest that AII activity partially compensates for the loss of adrenergic vasoconstrictors after acute renal denervation, because agents inhibiting either the generation or the action of AII result in greater vasodilation in this setting (11). These studies demonstrate a definite link and a complex interaction between renal adrenergic activity and the renin-angiotensin system. A next logical step is to examine whether or not the link between adrenergic and angiotensin systems is bidirectional in that inhibition of adrenergic activity could modulate the effects of AII on the dynamics of glomerular ultrafiltration. One hypothesis is that AII could either directly stimulate release of norepinephrine or modify reuptake of norepinephrine by an action on the renal nerve terminal which could magnify the increases in renal vascular resistance observed in vivo during either exogenous infusions of angiotensin $(1,2)$ or conditions in which AII is generated endogenously $(13,14)$. Alternatively, removal of normal renal adrenergic innvervation might magnify the renal hemodynamic response to infusion of AII by mechanisms that have not been fully delineated.

In this study we examined the changes in the dynamics of glomerular ultrafiltration produced by a given dose of AII in both normal, innervated rats and rats which were unilaterally denervated 4-6 d prior to the measurement period. The animals were plasma volume expanded during the measurement period to provide conditions of filtration pressure disequilibrium which permit an exact evaluation of the glomerular ultrafiltration coefficient and a fluid volume status in which both endogenous generation of AII and catecholamines should be minimized. Tissue catecholamines were measured in both innervated and denervated kidneys to establish the efficacy of the denervation procedure by documenting the reduction in tissue catecholamines after 4-6 d of denervation. We also examined the effect of subacute denervation on glomerular AII receptors to determine whether any change in receptor affinity or number contributed to altered renal hemodynamic response observed in subacutely denervated compared with normally innervated kidneys.

$\begin{array}{ll}\text { Glossary } & \\ \text { AR } & \text { afferent arteriolar resistance } \\ B_{\text {MAX }} & \text { maximum glomerular receptor binding } \\ \text { ER } & \text { efferent arteriolar resistance } \\ \overline{\text { EFP }} & \text { mean effective filtration pressure } \\ \text { FF } & \text { filtration fraction } \\ \text { GFR } & \text { glomerular filtration rate } \\ \text { LpA } & \text { glomerular ultrafiltration coefficient } \\ \text { MAP } & \text { mean arterial pressure } \\ \Delta P & \text { glomerular hydrostatic pressure gradient }\end{array}$




$\begin{array}{ll}P_{\mathrm{BS}} & \text { Bowman's space pressure } \\ P_{\mathrm{G}} & \text { glomerular capillary hydrostatic pressure } \\ \text { RBF } & \text { renal blood flow } \\ \text { RPF } & \text { renal plasma flow } \\ \text { RVR } & \text { renal vascular resistance } \\ \text { SNBF } & \text { single nephron blood flow } \\ \text { SNGFR } & \text { single nephron glomerular filtration rate } \\ \text { SNPF } & \text { single nephron plasma flow }\end{array}$

\section{Methods}

Experiments were performed on male Munich-Wistar rats with a weight range of $190-250 \mathrm{~g}$ at the time of the study. The animals were bred and maintained in an isolated colony housed at the San Diego Veterans Administration Medical Center.

Denervation procedure. 4-6 d prior to either the micropuncture experiment or harvesting of the kidneys for receptor analysis the rats were anesthetized with Brevitol (Eli Lilly and Co., Indianapolis, IN) intraperitoneally, and a flank incision was performed to expose the renal artery and nerves. Denervation of the left renal artery was accomplished under stereomicroscopic observation. The renal artery was stripped of its adventitia and subsequently coated with a solution of $10 \%$ phenol in absolute alcohol for a period of $15-20 \mathrm{~min}(12,15)$. The kidney and surrounding structures were protected from exposure to the phenol solution and the lymph vessels were left intact during the procedure. After denervation the animals were sutured, closed, and allowed to recover. Rats to be used for micropuncture studies as innervated controls also underwent the surgical procedure as the denervated rats but the renal pedicle and nerve remained untouched.

Preparation for micropuncture. The rats were anesthetized with inactin $(100 \mathrm{mg} / \mathrm{kg}$ body $\mathrm{wt})$ given intraperitoneally. A tracheostomy was performed (PE-240) and PE-50 catheters were placed in the left jugular vein, left femoral artery, bladder, and left ureter. Arterial blood pressure was monitored continuously throughout the studies with a P23dB GouldStatham (Oxnard, CA) pressure transducer and recorded on a Statham chart recorder. Body temperature was regulated on a heated table with a servo-controlled heating unit. Further surgical preparation for rat micropuncture was as previously described (16). Beginning $60 \mathrm{~min}$ prior to the micropuncture measurements the rats were infused with $2.5 \%$ body wt donor plasma and $1.25 \%$ body $\mathrm{wt} / \mathrm{h}$ isotonic $\mathrm{NaCl}-\mathrm{NaHCO}_{3}$ solution for $1 \mathrm{~h}$ followed by urinary replacement with isotonic $\mathrm{NaCl}-$ $\mathrm{NaHCO}_{3}$. An infusion of $\left[{ }^{3} \mathrm{H}\right]$ inulin (ICN, Irvine, CA) at a rate of $\sim 120$ $\mu \mathrm{Ci} / \mathrm{h}$ was initiated $60 \mathrm{~min}$ prior to the first micropuncture measurements and continued throughout the remainder of the study as a marker of glomerular ultrafiltration.

Micropuncture studies, control plasma volume expansion to AII infusion. Both the shams (innervated, $n=8$ ) and unilaterally denervated rats $(n=7)$ were submitted to the same micropuncture protocol. The left kidney was the micropunctured kidney in all cases. Measurements of glomerular dynamics were obtained during the control period. Pressures were measured in surface glomerular capillaries, Bowman's space, and the efferent arterioles or large "star" peritubular capillaries $(16,17)$. At least five proximal tubular collections were obtained to measure single nephron filtration rate (SNGFR). Efferent arteriolar (or large peritubular capillary) blood samples (at least three) were collected for determination of postglomerular blood protein concentration. All these measurements were obtained within a period of $\sim 60 \mathrm{~min}$. Renal vein blood samples were obtained to measure renal plasma and renal blood flow at the end of each micropuncture period. After completion of these initial measurements, AII (Asp-1, Ile-8; Beckman Instruments, Inc., Palo Alto, CA) was infused i.v. starting at $5 \mathrm{ng} / 100 \mathrm{~g}$ body wt (BW) min and gradually increased until blood pressure was elevated $20 \mathrm{mmHg}$ higher than the control period. The dosage sufficient to maintain $20 \mathrm{mmHg}$ blood pressure elevation was continued throughout the remainder of the study. After a 20-min stabilization period, the measurements were repeated.
At the end of the second measurement period the kidneys were weighed and then snap-frozen in liquid nitrogen for analysis of tissue catecholamine concentrations.

Receptor analysis studies in isolated glomeruli. All the rats were denervated as described previously. 4-6 d after the denervation procedure the animals were anesthetized with inactin i.p., and both the left denervated and the right innervated kidneys were harvested within $15 \mathrm{~min}$ of anesthesia and placed in cold-filtered isotonic $\mathrm{NaCl}-\mathrm{NaHCO}_{3}$ solution. The animals were euvolemic prior to the harvesting of the kidneys. The cortical tissue was then placed on a 140-mesh screen $(106 \mu \mathrm{m}, \mathrm{W}$. S. Tyler Co., Mentor, $\mathrm{OH}$ ) and pressed through the screen and rinsed with filtered $\mathrm{NaCl}-\mathrm{NaHCO}_{3}$ solution. This suspension is then placed on a 200 -mesh screen (75 $\mu \mathrm{m}, \mathrm{W}$. S. Tyler Co.) and washed. The glomeruli remain on top of the screen. The glomeruli were then transferred to centrifuge tubes and slow centrifugation and washing with cold isotonic $\mathrm{NaCl}-\mathrm{NaHCO}_{3}$ solution was performed several times until a $>95 \%$ purity of isolated glomeruli was achieved with yields of $98,000 \pm 14,000$ glomeruli for the left kidneys and $113,000 \pm 25,000$ for the right kidneys ( $n=7$ kidneys, NS) for each assay. This procedure is a modification of the technique by Kreisberg (18). These yields resulted in an average membrane aliquot ( 28 aliquots per assayed group) of $0.140 \pm 0.034 \mathrm{mg}$ protein for the left kidneys and $0.154 \pm 0.016 \mathrm{mg}$ protein for the right kidneys in the receptor assays performed in this study. The glomeruli were analyzed for AII receptors with comparison of the unilateral denervated left kidneys to the contralateral right kidneys in the following fashion. Four separate AII receptor assays were performed in which denervated and innervated kidneys were compared in a paired analysis. Seven rats (or 14 kidneys) were utilized in each assay. A fifth assay was performed in which denervated and innervated kidneys from the same rats were analyzed along with the left and right kidneys from seven undisturbed rats. Binding curves were determined in the same assay in order to determine which kidney, denervated or centrally innervated, represented the normal values. In each assay glomeruli were harvested from (a) denervated kidneys, $(b)$ contralaterally innervated kidneys, and $(c)$ in the case of one assay, left and right normal kidneys, and AII receptors were analyzed in the same assay in order to provide a direct intra-assay comparison of AII receptors among denervated, contralateral innervated, and normal kidneys. Therefore two or four binding curves for Scatchard analysis were generated from each assay and the data from all assays were submitted to analysis of covariance.

The AII receptor assay employs the following method. The isolated glomeruli were maintained on ice, weighed, and then disrupted at $0^{\circ} \mathrm{C}$ with a Polytron (Brinkmann Instruments, Inc., Westbury, NY) using a power setting of 6 for $15 \mathrm{~s}$, in $3 \mathrm{ml}$ of homogenization buffer $(50 \mathrm{mM}$ Tris- $\mathrm{HCl}, 150 \mathrm{mM} \mathrm{NaCl}$, and $3 \mu \mathrm{M}$ phenylmethylsulfunyl fluoride $\mathrm{pH}$ 7.2 , measured at $25^{\circ} \mathrm{C}$ ). The homogenate was centrifuged at $28,000 \mathrm{~g}$ (Sorvall RC5, DuPont-Sorvall, Newtown, CT) for $20 \mathrm{~min}$ and the pellet resuspended in $3 \mathrm{ml}$ of hypotonic $50 \mathrm{mM}$ Tris-HCl buffer, $\mathrm{pH} 7.2$, with a brief (1-2 s) rehomogenization to lyse red cells. Homogenization buffer (containing saline) was immediately added, and the sample was recentrifuged as above. The resulting pellet (i.e., crude membrane fraction) was resuspended in the Tris-saline buffer to a concentration of 6-12 mg protein $/ \mathrm{ml}$ and assayed. For the ligand-binding experiments, an aliquot of the membrane suspension $(40 \mu \mathrm{l})$ was incubated in total volume of $150 \mu \mathrm{l}$ of assay medium containing $0.5 \%$ bovine serum albumin (Pentex, Miles Laboratories, Inc., Elkhart, IN) and various concentrations of radioligand for Scatchard analysis (0.25-12 nM AII). Nonspecific binding was determined with $1 \mu \mathrm{M}$ unlabeled $\mathrm{val}^{5}$-AII in addition to the ${ }^{125} \mathrm{I}$ labeled peptide. All assays were run in duplicate. Specific binding was defined as total minus nonspecific. The time of incubation was terminated after $30 \mathrm{~min}$ by the addition of $3 \mathrm{ml}$ of ice-cold saline to each assay tube, and the contents immediately filtered under vacuum through glass fiber filter discs (GF/C). An additional $3 \mathrm{ml}$ of cold saline was used to rinse the filter. The entire filtering sequence took $\sim 10 \mathrm{~s}$ for each tube. Radioactivity retained on the filter dises was determined with Packard model 8000 gamma-counter (Packard Instrument Co., Inc., Downers Grove, IL) and protein in the homogenates determined by Lowry et al. (19). 
The receptor-binding data were analyzed with the Ligand Program using a Tektronix computer (Beaverton, OR) interfaced with the University VAX computer. This analysis is a modification of a previously published AII receptor assay (20). In this receptor assay there was no addition of $\mathrm{Mg}^{2+}, \mathrm{Ca}^{2+}$, EDTA, or dithiothreitol which has been shown to affect receptor number and binding affinities $(21,22)$. Degradation of ${ }^{125}$ I-AII present in the incubation medium was assessed by reverse-phase high pressure liquid chromatography which indicated a $75-80 \%$ integrity of the ligand during the assay.

Analytical methods. Total kidney filtration rates were calculated as previously described (16). ${ }^{3} \mathrm{H}$ counts in plasma, urine, and tubular fluid were measured in a model 2425 Packard scintillation counter (Packard Instrument $\mathrm{Co}$.). Pressure measurements were obtained with a servo nulling device utilizing 1-3- $\mu \mathrm{m}$ glass tip pipettes (23). Pressure measurements were recorded in glomerular capillaries, Bowman's space, proximal tubules, and "star" vessel peritubular capillaries as previously described $(16,17,23)$.

Systemic plasma protein concentration was determined by analysis of femoral artery blood. Efferent arteriolar protein concentration was obtained from "star" vessels on the kidney surface. All protein collections were then analyzed by a microadaptation (24) of the method of Lowry et al. (19) as previously described by this laboratory $(16,17)$. Oncotic pressure of systemic protein samples $\left(C_{\mathrm{A}}\right)$ and efferent arteriolar samples $\left(C_{\mathrm{E}}\right)$ were determined by the following relationship: $\pi=1.74 C+0.28 C^{2}$, which is a simplification of the empirical relationship for a range of 4-10 $\mathrm{g} \%$ defined by Landis and Pappenheimer (25): $\pi=2.1 C+0.16 C^{2}$ $+0.009 C^{3}$. This equation defines the relationship between oncotic pressure and protein concentrations during normal conditions when $\sim 50 \%$ of the total protein is albumin.

Norepinephrine, epinephrine, and dopamine concentration in both innervated and denervated kidney tissues were determined by a highly sensitive radioenzymatic assay for catecholamines previously published (26) and utilized by this laboratory $(11,27)$.

Calculations. Single nephron plasma flow (SNPF) was calculated from the following relationship: SNPF $=\mathrm{SNGFR} /\left(1-C_{\mathrm{A}} / C_{\mathrm{E}}\right)$, where $C_{\mathrm{A}}$ is the systemic and $C_{\mathrm{E}}$ is the "star" peritubular protein concentration. Single nephron blood flow (SNBF) was determined from the following relationship: $\mathrm{SNBF}=\mathrm{SNPF} /(1-\mathrm{Hct})$, where Hct is the systemic hematocrit expressed as a fraction of one. Afferent and efferent arteriolar resistances were calculated as previously described $(16,17)$.

The determinants of SNGFR are defined as SNGFR $=\mathrm{LpA} \cdot \overline{\mathrm{EFP}}$, where LpA represents the glomerular ultrafiltration coefficient and $\overline{\mathrm{EFP}}$ is the mean effective filtration pressure across the glomerular capillary. EFP along the glomerular capillary length $\left(x^{*}\right)$ is described as: $\operatorname{EFP}_{x^{*}}=(\Delta P-\pi) x^{*}$. The $\overline{E F P}$ is defined by the following equation: $\overline{\mathrm{EFP}}=\int(\Delta P-\pi) \mathrm{d} x^{*}=\int \mathrm{EFP} \mathrm{d} x^{*}$. The $\mathrm{EFP}_{x^{*}}$ curve and LpA were determined by an iterative procedure described previously by this laboratory (28). Specific values for LpA and $\overline{\mathrm{EFP}}$ could be determined in each rat because plasma volume expansion caused a condition of filtration pressure disequilibrium at the efferent end of the glomerular capillary in this study.

Calculations for whole kidney glomerular filtration rate (GFR), filtration fraction (FF), renal plasma flow (RPF), and renal blood flow (RBF) are as previously described (28). Renal vascular resistance (RVR) was calculated from the following relationship: $R V R=(M A P-3 \mathrm{mmHg})$ $\mathrm{RBF}$, where $3 \mathrm{mmHg}$ is assumed to be the renal vein pressure.

Statistical analysis. Significance of data between control and experimental conditions was determined by analysis of variance and paired Student's $t$ test where appropriate $(29,30)$. Comparisons between groups were analyzed by unpaired $t$ test to determine significant differences. Analysis of differences in receptor number from multiple Scatchard analyses was performed by analysis of covariance (30). All data values are given as the means \pm standard error of the mean.

\section{Results}

Effect of subacute unilateral renal denervation on renal tissue catecholamines. A 4-6-d unilateral renal denervation significantly decreased renal tissue norepinephrine concentrations. The denervated kidney exhibited tissue norepinephrine levels of $0.5 \pm 0.3 \mathrm{pg} / \mathrm{mg}$ tissue wt, values not different from 0 , significantly in contrast to the contralateral right kidney value of $5.7 \pm 0.7 \mathrm{pg} /$ $\mathrm{mg}$ wet tissue wt $(P<0.01)$. There was no difference in tissue norepinephrine between left (sham denervated) and right kidneys in the sham group $(5.5 \pm 0.3$ vs. $5.3 \pm 0.5 \mathrm{pg} / \mathrm{mg}$ wet tissue wt, respectively). These data indicate the efficacy of the denervation procedure in substantially reducing adrenergic activity to the denervated kidney.

Effect of AII on systemic blood pressure and whole kidney function. AII was infused intravenously, gradually increasing the dose until mean arterial pressure (MAP) was elevated $20 \mathrm{mmHg}$ above the control period in both unilaterally denervated (DNX) and sham rats. The increase in MAP after AII infusion is depicted in Table I. The $\triangle M A P$ for the DNX was $20 \pm 2 \mathrm{mmHg}$ and $21 \pm 2$ $\mathrm{mmHg}$ for the shams. The AII dose required was 11.0 0.2 $\mathrm{ng} \cdot 100 \mathrm{~g} \mathrm{BW}^{-1} \cdot \mathrm{min}^{-1}$ for the DNX group and $10.9 \pm 0.3 \mathrm{ng} \cdot 100$ $\mathrm{g} \mathrm{BW}^{-1} \cdot \mathrm{min}^{-1}$ for the sham group. These data demonstrate that the systemic response to a given dose of AII was equivalent in both sham and DNX rats. The effect of AII infusion on whole kidney function (left kidney) for both sham and DNX groups is shown in Table I. DNX resulted in a significantly lower RVR in the control period compared with the shams $(P<0.05)$, although there was no significant difference by unpaired comparison in RBF between shams and DNX. After AII infusion RVR

Table I. Response to AII Infusion on MAP and Whole Kidney Function

\begin{tabular}{|c|c|c|c|c|c|c|c|}
\hline & MAP & GFR & $\mathbf{F F}$ & RPF & Het & RBF & RVR \\
\hline & $m m H g$ & $\mathrm{ml} / \mathrm{min} \cdot \mathrm{gKW}$ & $\%$ & $\mathrm{ml} / \mathrm{min} \cdot \mathrm{gKW}$ & $\%$ & $\mathrm{ml} / \mathrm{min} \cdot \mathrm{gKW}$ & $\times 10^{5} \cdot$ dymes $\cdot \mathrm{s} \cdot \mathrm{cm}^{-\mathrm{s}}$ \\
\hline \multicolumn{8}{|l|}{ Group $1(n=8)$} \\
\hline Shams & $118 \pm 3$ & $1.16 \pm 0.05$ & $26 \pm 2$ & $4.7 \pm 0.6$ & $43 \pm 1$ & $8.2 \pm 1.0$ & $12.3 \pm 1.0$ \\
\hline Shams + AII & $139 \pm 3^{*}$ & $1.09 \pm 0.05$ & $40 \pm 3^{*}$ & $2.8 \pm 0.3^{*}$ & $43 \pm 1$ & $4.9 \pm 0.4^{*}$ & $22.8 \pm 1.1^{*}$ \\
\hline \multicolumn{8}{|l|}{ Group $2(n=7)$} \\
\hline DNX & $109 \pm 4$ & $1.23 \pm 0.06$ & $22 \pm 3$ & $5.9 \pm 0.8$ & $44 \pm 1$ & $10.5 \pm 1.5$ & $8.7 \pm 0.8 \ddagger$ \\
\hline DNX + AII & $129 \pm 5^{*}$ & $0.94 \pm 0.10^{*}$ & $43 \pm 2^{*}$ & $2.2 \pm 0.2^{*}$ & $42 \pm 1$ & $3.8 \pm 0.4^{*}$ & $31.2 \pm 3.8^{*} \ddagger$ \\
\hline
\end{tabular}

* $P<0.05$ compared with first period. $\ddagger P<0.05$ compared with sham rats in corresponding experimental period. 


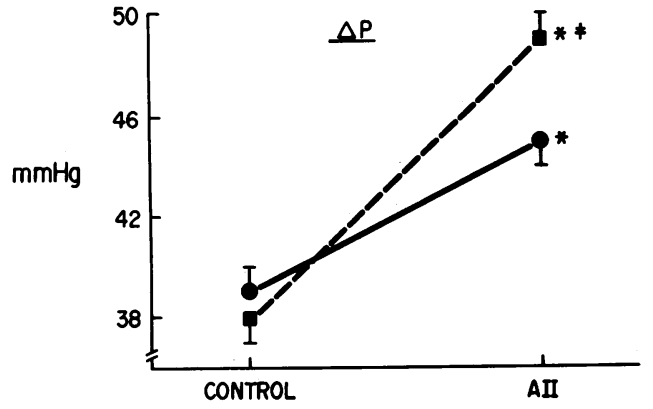

Figure 1. Effect of AII on the glomerular hydrostatic pressure gradient $(\Delta P)$ in innervated and denervated rats. (๑) Innervated rats; ( $(\bullet)$ denervated rats. In the denervated rats $\Delta P$ increased from 38 to $49 \mathrm{mmHg}$ after administration of AII. This increase in $\Delta P$ represents a significantly greater response to the same dose of AII than observed in innervated shams. ${ }^{*} P<0.05$ compared with control period; $¥ P<0.05$ with innervated shams.

increased significantly in both groups; however, the RVR in the DNX kidneys increased to a value greater than the shams ( $P$ $<0.05)$. This increase in RVR after AII infusion in the DNX group was more than twice the increase observed in the shams either when expressed as absolute increases or percentage increases in RVR $(P<0.05)$. The resulting percentage reduction in RPF was also nearly twice as great in the DNX kidney $(57 \pm 7 \%$ vs. $34 \pm 9 \%$ in innervated kidneys, $P<0.05$ ). RBF decreased by $60 \pm 6 \%$ in the DNX kidney and by $34 \pm 8 \%$ in innervated kidneys, $P<0.05$ ). These data indicate that there was an increased response of the RVR and a greater decrease in RPF and RBF with systemic AII infusion after subacute denervation.

Effect of AII on the dynamics of glomerular ultrafiltration. The specific effects of the exogenous AII on the dynamics of glomerular ultrafiltration in both sham and DNX rats are shown in Table II. There was no change in the glomerular capillary hydrostatic pressure after the AII infusion in either group; however, after AII infusion there was a small but significantly greater increase in glomerular capillary hydrostatic pressure $\left(P_{\mathrm{G}}\right)$ in the DNX group compared with the shams $(P<0.05)$. After AII infusion Bowman's space pressure $\left(P_{\mathrm{BS}}\right)$ decreased in both shams and DNX (Table II). The decrease in $P_{\mathrm{BS}}$ in the shams was $6.7 \pm 0.9 \mathrm{mmHg}$ which was significantly less than the decrease in the DNX group $(\Delta=10.1 \pm 1.1, P<0.05)$. The greater reduction in $P_{\mathrm{BS}}$ and significantly higher $P_{\mathrm{G}}$ in the DNX group after AII infusion resulted in not only a greater increase in glomerular hydrostatic pressure gradient $(\Delta P)$ in the DNX group $(\Delta=5.9 \pm 1.5 \mathrm{mmHg}$ in shams vs. $10.7 \pm 1.4 \mathrm{mmHg})$ but also the absolute value for the $\Delta P$ was higher (Table II, Fig. $1, P$ $<0.05)$. These data demonstrate that subacute denervation not only failed to reduce AII-induced increase in $\Delta P$ but the increase in $\Delta P$ was even larger than in the shams. SNGFR decreased in both shams $\left(\Delta=7 \pm 2 \mathrm{nl} \cdot \mathrm{min}^{-1} \cdot \mathrm{g}\right.$ kidney wt $\left.(\mathrm{KW})^{-1}\right)$ and in $\operatorname{DNX}\left(\Delta=13 \pm 2 \mathrm{nl} \cdot \mathrm{min}^{-1} \cdot \mathrm{gKW}^{-1}\right)$ after AII infusion and this decrease was not significantly different between the two groups (Table II, Fig. 2). However, SNPF was higher in the DNX group compared to the shams prior to the AII infusion (213 \pm 17 vs. $\left.161 \pm 9 \mathrm{nl} \cdot \min ^{-1} \cdot \mathrm{gKW}^{-1}, P<0.05\right)$. The decrease in SNPF after AII infusion was greater in the DNX group $(\Delta=126 \pm 20$ $\left.\mathrm{nl} \cdot \mathrm{min}^{-1}\right)$ than in the shams $\left(\Delta=59 \pm 9 \mathrm{nl} \cdot \min ^{-1} \cdot \mathrm{gKW}^{-1}\right.$, $P<0.02$, Fig. 2). The infusion of exogenous AII resulted in a significantly lower SNPF in the DNX group $\left(87 \pm 4 \mathrm{nl} \cdot \mathrm{min}^{-1} \cdot \mathrm{gKW}^{-1}\right)$ compared to the shams $(102 \pm 5$ $\left.\mathrm{nl} \cdot \min ^{-1} \cdot \mathrm{gKW}^{-1}\right)$. Because there was no change in the hematocrit after AII infusion in either group, the changes observed in SNPF were paralleled by the changes in SNBF (Table II). These data suggest that there were significant differences in afferent (AR) and efferent (ER) arteriolar resistance between the two groups. AR doubled after AII infusion in the shams. However, the same dose of AII in the DNX group more than tripled AR (Table II). This greater increase in AR owing to the infusion of AII did not result in higher value for AR in the DNX group compared with the shams but was the consequence of subacute unilateral denervation decreasing AR to values less than the shams (Fig. 3, $P<0.05$ ) prior to AII infusion. There was no significant difference in (ER) between sham and DNX groups prior to the AII infusion (Fig. 3, Table II). After the AII infusion ER increased significantly in both shams and DNX (Fig. 3, Table II). However, the increase in ER in the DNX group $(\Delta=23 \pm 2$

Table II. Effect of AII Infusion on the Dynamics of Glomerular Ultrafiltration in Both Innervated Shams and DNX Rats

\begin{tabular}{|c|c|c|c|c|c|c|c|c|c|c|c|c|}
\hline MAP & $P_{\mathrm{G}}$ & $P_{\mathrm{BS}}$ & $\Delta P$ & SNGFR & SNPF & SNBF & AR & ER & $\pi_{\mathrm{A}}$ & $\pi_{E}$ & $\overline{\mathrm{EFP}}$ & LpA \\
\hline & & ${ }_{\mathrm{ig}} \mathrm{Hg}$ & & & $i^{-1}$ & & $\begin{array}{l}\text { dyne } \\
\times 10\end{array}$ & $\mathrm{~cm}^{-\mathrm{s}}$ & & $m m H$ & & \\
\hline
\end{tabular}

Group 1

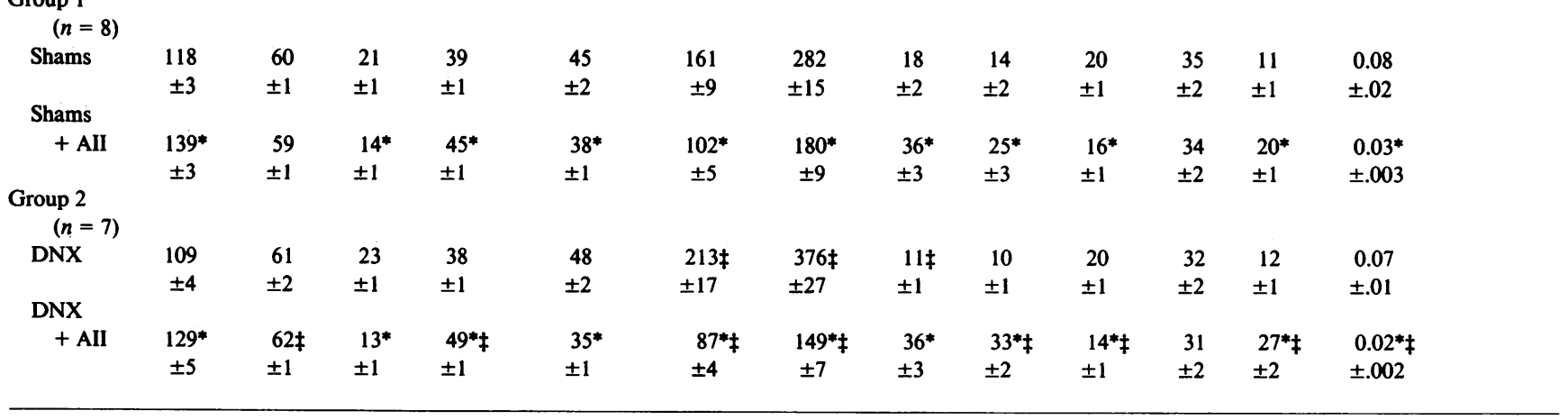

* $P<0.05$ compared with respective control. $¥ P<0.05$ compared with respective period in sham group. 

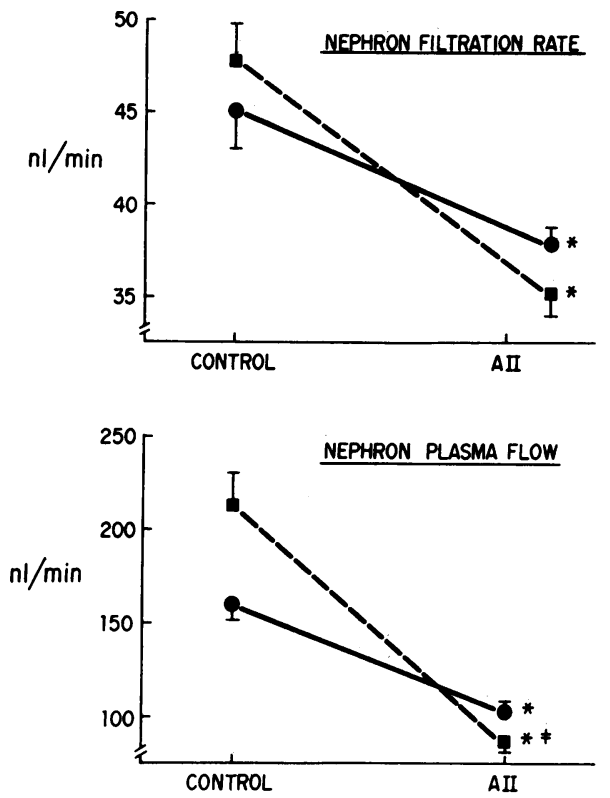

Figure 2. Effect of AII infusion on nephron filtration rate and nephron plasma flow in (๑) innervated sham and ( $\bullet$ ) denervated rats. In both groups, nephron filtration rate significantly decreased in response to All infusion. The magnitude of the decrease in filtration rate was not significantly different between the two groups. However; in the denervated group, not only was plasma flow significantly greater than the innervated rats in the control period, but also nephron plasma flow decreased to a value significantly lower in denervated rats after AII infusion compared with shams. ${ }^{*} P<0.05$ compared with control period and $\ddagger P<0.05$ compared with innervated shams.
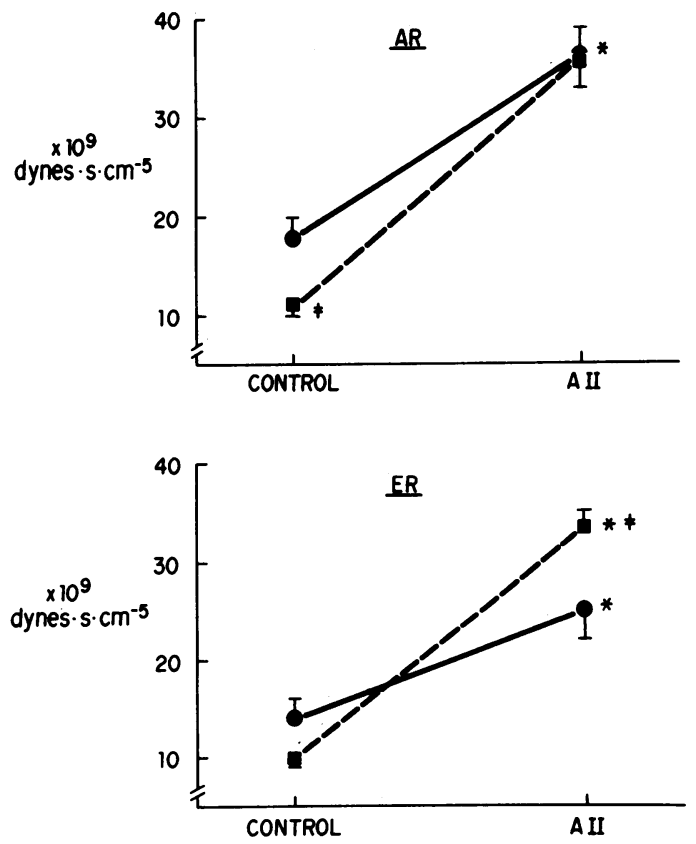

Figure 3. Effect of AII infusion on AR and ER in (๑) innervated and (a) denervated rats. In denervated rats, the control AR was signifcantly less than the shams. The lower AR resistance contributed to a higher nephron plasma flow in those denervated rats. ER increased to a significantly greater extent after AII infusion in the denervated group than in the sham innervated kidneys. $\times 10^{9}$ dynes $\left.\cdot \mathrm{s} \cdot \mathrm{cm}^{-5}\right)$ was greater than in the sham kidney $(\Delta$ $=11 \pm 2 \times 10^{9}$ dynes $\left.\cdot \mathrm{s} \cdot \mathrm{cm}^{-5}, P<0.01\right)$ and resulted in an absolute value that was greater than the shams (Fig. 3, Table II, $P<0.05$ ). Subacute denervation resulted in both a lower AR prior to the AII infusion and a significantly increased ER after AII infusion, which suggests an increased renal vascular response to a given dose of AII after DNX.

The LpA was not different between shams and DNX prior to the AII infusion, and AII infusion decreased LpA dramatically in both groups (Table II). However, LpA was significantly lower after AII infusion in the DNX group compared with the shams $(P<0.05$, Table II). This further decrease in LpA was offset by the greater EFP in the DNX group after AII compared with shams maintaining post-AII infusion SNGFR at equivalent values in both groups (Table II).

Both the whole kidney RVR response and the quantitative difference in the dynamics of glomerular ultrafiltration between the sham and DNX groups to the same rate of infusion of AII provides clear evidence that subacute unilateral renal denervation increases the response of the renal vasculature and glomerular capillaries to this dose of AII.

Effect of subacute unilateral renal denervation on glomerular AII receptors. Glomerular AII receptors were measured in isolated glomeruli preparations from both denervated left kidneys and contralateral right controls harvested from the same rats and the results of these assays are depicted in Table III (four assays, seven rats per assay). Maximum binding of ${ }^{125} \mathrm{I}-\mathrm{AII}$ was measured by Scatchard analysis and was significantly greater ( $P$ $<0.01$ ) in glomeruli from the denervated kidney compared with the contralateral right kidney (Table III). Denervated and paired contralateral kidneys were always evaluated in the same assay. The receptor dissociation constant $\left(K_{\mathrm{D}}\right)$ was not different between denervated and contralateral innervated kidneys. These data on glomerular receptors and the data from the glomerular hemodynamic studies would suggest that there is an increase in AII receptors in glomeruli from denervated kidneys. However, these data did not rule out the possibility of a reduction in glomerular AII receptor number in the contralateral kidney as opposed to an increase in AII receptor number in the denervated kidney. For this reason we performed a single analysis in which glomeruli from denervated and contralateral innervated kidneys $(n=7$ rats) as well as glomeruli from left and right kidneys in untouched control rats $(n=7)$ were evaluated in the same assay. There was no difference in maximum glomerular AII receptor binding $\left(B_{\mathrm{MAX}}\right)$ between left and right control kidneys ( $485 \pm 14$ vs. $510 \pm 8$ $\mathrm{fm} / \mathrm{mg}$ protein, respectively). $B_{\mathrm{MAX}}$ from the contralateral innervated right kidney in the DNX rats was also not different

Table III. Effect of Subacute Denervation of Glomerular AII Maximal Receptor Binding and Dissociation Constant

\begin{tabular}{lcl}
\hline & Maximum binding & Dissociation constant \\
\hline & fmol/mg protein & $\times 10^{-9} M$ \\
& $1196 \pm 267^{*}$ & $1.8 \pm 0.3$ \\
Denervated & $612 \pm 89$ & $1.7 \pm 0.1$
\end{tabular}

Data are based upon four paired assays conducted in the same ratsseven rats evaluated per assay.

* $P<0.01$ compared with contralateral. 
from the controls ( $490 \pm 38 \mathrm{fm} / \mathrm{mg}$ protein). Only glomeruli from denervated kidneys demonstrated an increase in $B_{\text {MAX }}$ compared with the controls $(627 \pm 14 \mathrm{fm} / \mathrm{mg}$ protein, $P<0.05$ compared with contralateral right glomeruli, $P<0.01$ compared with either control glomeruli ( $n=$ seven kidneys per group). There was no significant difference in values for the dissociation constant in any of the four groups which varied from 1.2 to $1.5 \times 10^{-9} \mathrm{M}$. Values from this single assay for $B_{\text {MAX }}$ appeared lower than values reported in the other four assays. However in each of five assays, paired comparisons revealed significantly higher values for $\boldsymbol{B}_{\mathrm{MAX}}$ in the denervated kidneys. These data demonstrate that the increased vascular response to exogenous infusions of AII in the subacute denervated kidneys is correlated with a significant increase in glomerular AII receptors.

\section{Discussion}

The data of this study demonstrate that removal of renal adrenergic input for several days results in major modifications in the glomerular hemodynamic response to infusion of AII. According to our original hypothesis, it was proposed that a portion of the renal hemodynamic response to AII might be mediated by enhancement of functional renal adrenergic activity via AII effects on norepinephrine reuptake and release. Had such a formulation been correct, glomerular hemodynamic responses to AII would have been decreased in denervated kidneys. Examination of the resulting data demands a quite different conclusion. Subacute renal denervation, as evidenced by nearly total renal tissue catecholamine depletion, resulted in marked enhancement of glomerular hemodynamic responses to AII infusion when compared with the normally innervated condition. In addition to the greater functional response of the denervated kidney to AII infusion, we also observed an increase in glomerular AII receptors from kidneys which had been deprived of renal nerve traffic activity for a period of 4-6 d compared with the contralateral innervated kidneys.

Other studies have examined certain aspects of renal function after similar periods of renal denervation (31), but the current study represents the first direct examination of glomerular hemodynamics after subacute denervation. This procedure permitted the examination of the effects of AII on glomerular hemodynamics without the potential secondary effect of AII on the intrarenal release and reuptake of norepinephrine $(32,33)$. The subacute denervation protocol provided an experimental model in which nerve traffic activity was effectively eliminated for 4-6 d, but was of a sufficiently short duration that reinnervation of the kidney had not occurred (31). However, because there is evidence in the literature that renal adrenergic activity is important to renin release and angiotensin generation (3437 ), it is likely that subacute renal denervation led to reduction in the intrarenal generation of AII. Subacute denervation did decrease total RVR as a result of a marked decrease in AR. Normally, a decrease in AR should increase glomerular capillary hydrostatic pressure but there was also a numerical decrease in ER although this trend did not achieve statistical significance. The decrease in resistance during subacute denervation resulted in increased nephron blood flow. These results suggests that adrenergic activity does contribute to normal renal vascular tone, at least under these experimental conditions.

The effect of AII on glomerular dynamics in the sham rats was quite similar to the results published previously from this laboratory with the same systemic blood pressure response $(1,2)$, indicating the reproducibility of this experimental protocol. In the denervated animal, the same blood pressure response was achieved with a dose of AII which was the same as utilized in sham rats, such that the differences observed in renal hemodynamics were not the result of either differing systemic blood pressure responses or concentrations of circulating AII.

Many studies have revealed a specific interaction between renin release and renal adrenergic activity in which increases in adrenergic activity have been shown to stimulate renin release $(8,10)$. This study was specifically designed to determine if the expression of AII response on renal hemodynamics is modified with the deletion of renal adrenergic activity. The present study demonstrates that with subacute renal denervation, the renal vascular response was magnified and the same dose of AII increased both AR and ER to a greater extent and resulted in a lower value for LpA compared with the sham kidneys. Utilizing this experimental protocol, we could not demonstrate that renal adrenergic innervation enhanced the glomerular hemodynamic and renovascular effects of infused AII via AII enhancement of adrenergic vascular effects. However, these studies did not specifically exclude some degree of AII effect in magnifying adrenergic effects via influences on norepinephrine reuptake and release in the normal physiologic condition. It is also conceivable that if AII infusion causes extrarenal release of norepinephrine and elevation in plasma values, the denervated kidney might exhibit an enhanced sensitivity to circulating norepinephrine.

The greater effect of AII on RVR in subacute renal denervated rats compared to sham rats was associated with an increase in glomerular AII receptors in the denervated kidney compared with both the contralateral kidney and bilaterally innervated kidneys. Although we were not able to measure AII receptors in either afferent or efferent arterioles except as part of the isolated glomeruli, it is a logical assumption that the changes in AII receptor number in these vessels should parallel the changes in AII receptor number in the glomerulus 4-6 d after denervation. There was no change in AII receptor binding affinity after subacute denervation. The fact that an increased vascular response was observed after denervation indicates that cessation of renal adrenergic activity must provide some stimulus to increase AII receptor number. Importantly, the differences in glomerular AII receptor number observed were not due to reductions in AII receptors in the contralateral, innervated kidney in that these values were equal to values in bilaterally innervated kidneys. One reasonable scenario is that after the elimination of basal renal nerve activity the stimulus to generate endogenous renin and AII is reduced, and local intrarenal AII concentration decreased, resulting in secondary upregulation of AII receptor number. With an exogenous infusion of AII the increase in glomerular AII receptors should increase the renal vascular response when compared to normal, innervated rats. This formulation could potentially explain the observations contained within this study.

The measurement of glomerular AII receptors requires exacting techniques and a survey of the literature in this area demonstrates a varied $B_{\mathrm{MAX}}$ and $K_{\mathrm{D}}$ among several laboratories $(21,22,38-40)$. Some of this variation can be attributed to the addition of various concentrations of either monovalent or bivalent cations to the incubation medium as was so elegantly demonstrated by Douglas et al. (21). Also, the absolute number of binding sites and receptor binding affinity can be altered by 
the addition of bisodium EDTA to the assay protocol (22). However, examination of these studies also indicate that even if one receptor assay protocol is utilized, interassay variation does occur $(21,22,38-40)$. The experimental protocol for the glomerular AII receptor assay utilized in this study was designed to minimize the effects of interassay variation in the analysis of the data by incorporating assessment of glomeruli from $(a)$ denervated kidneys, $(b)$ contralateral, innervated kidneys, and $(c)$ bilaterally innervated kidneys in the same assay for comparison. Because some variation in $B_{\text {MAX }}$ is encountered among assays, this protocol, utilizing the internal pairing procedure, provided intrassay comparisons. Although the absolute values for $B_{\operatorname{MAX}}$ and $K_{\mathrm{D}}$ may be somewhat variable, we are confident that $B_{\mathrm{MAX}}$ in the subacutely denervated kidney was increased compared with normal kidneys and that the $B_{\text {MAX }}$ was not reduced in the contralaterally innervated kidneys.

The rats utilized for the All receptor assay were in a euvolemic condition and the rats from which glomerular hemodynamic data were obtained were plasma volume expanded with both groups anesthetized. However, because of surgical volume losses associated with micropuncture experiments, the actual plasma volume difference was probably small. Although the exact values for $B_{\text {MAX }}$ may be affected by this small volume difference, it is unlikely to alter the observation that the denervated kidney has an increased $B_{\operatorname{MAX}}$ compared with the contralateral innervated kidneys.

Denervation may have selectively affected angiotensinase activity in the kidney and resulted in different measured binding activities between denervated and control kidneys. However, reverse-phase high pressure liquid chromatography testing of the ligand indicated a $75-80 \%$ integrity throughout the 30-min incubation in innervated kidneys. Also, the maximum bound to free ratios did not exceed 5\% in any of the AII receptor assays such that differing angiotensinase activity in the respective kidneys could not have explained the observed differences in AII receptor number.

There was increased vasoconstriction at both the afferent and efferent arteriole with AII in both sham and denervated rats. There are studies in the literature that have proposed that the action of AII is localized to the efferent arteriole with no major effect upon the afferent arteriole $(41,42)$. Edwards (43) has shown in isolated arterioles that AII did not cause vasoconstriction of the afferent arteriole but did constrict the efferent arteriole. However, a recent study from this laboratory has demonstrated that both AII and adrenergic activity contribute to the maintenance of AR in the condition of chronic salt depletion independent of AII effects on renal adrenergic activity (13).

This study did not completely address the interesting question of whether or not the observed increase in responsiveness of the renal vasculature to AII after subacute unilateral renal denervation was sufficient to compensate for the loss of adrenergic activity to the kidney in either the awake state or in euvolemic conditions. AR was decreased in dennervated kidneys in the plasma expanded condition when compared with innervated kidneys, suggesting that increased AII receptor number alone was not sufficient to compensate for the loss of renal adrenergic input. However, as we have postulated, subacute loss of renal adrenergic activity also should result in a reduction in local renin and AII generation and concentration within the denervated kidney. Therefore, it is impossible to determine from these results the exact mechanism leading to a lower renal vascular resistance in the denervated kidney, however, it is likely the result of a reduction in both adrenergic and angiotensin II responses to the stress of surgery and anesthesia.

The results of the current study require comparison to results recently obtained by this laboratory after acute unilateral renal denervation in the hydropenic rat (12). It can be assumed that in the hydropenic condition and under the stress of surgery and anesthesia, renal nerve activity must be high. Acute removal of renal nerves resulted in modest afferent arteriolar dilation, an increase in the $\Delta P$, a reduction in LpA, and a constancy of nephron filtration rate (12). It can also be safely assumed that the intrarenal concentration of AII was high and not greatly reduced by acute denervation. In fact, the increase in $\Delta P$ and reduction in LpA observed suggested an enhanced AII effect after acute renal denervation. Treatment with a converting enzyme inhibitor resulted in marked vasodilation in acutely denervated kidneys, normalization of $\Delta P$ and $\mathrm{LpA}$, and an increase in nephron filtration rate, effects not observed in the innervated kidney. We interpreted these results as suggesting that acute denervation somehow acutely increased AII activity, possibly owing to the large reduction in proximal tubular reabsorption and subsequent activation of some feedback mechanism generating AII release. The results of the current study differ significantly, especially because local intrarenal AII concentration was likely to be significantly reduced 4-6 d after denervation, an influence that probably contributed to the greater glomerular AII receptor number. We did not exclude the possibility in the prior acute renal denervation study that glomerular AII receptors were also increased, but this seems much less likely over such a short time period ( $\sim 30 \mathrm{~min}$ ). In addition, more chronic denervation results in major renal vasodilation, while acute denervation did not (12).

The results of the current study also complement data derived in another recent study from this laboratory (11). We examined the renal functional effects in response to moderate renal nerve stimulation in control rats and rats in which intrarenal angiotensin activity was decreased by either AII receptor blockers or converting enzyme inhibitor. Reductions in intrarenal AII activity markedly diminished the RVR to renal nerve stimulation compared to the response observed in control rats. The current study examined the opposite relationship, the effect of removal of renal adrenergic activity upon the glomerular hemodynamic response to infused AII. It is of interest that, whereas the removal of intrarenal AII effects diminished the glomerular hemodynamic influence of adrenergic stimulation, the prior removal of renal adrenergic activity resulted in enhancement of the RVR to AII, probably by indirect mechanisms.

The concurrent findings of increased renal sensitivity to AII infusion, as indexed by a greater glomerular hemodynamic response to infused AII, and an increase in glomerular AII receptor number in subacutely denervated kidneys remain only an interesting and provocative correlation and do not prove unequivocally a causal relation between increased AII receptors and increased AII renovascular sensitivity. However, the coincidence of these observations does make this conclusion quite logical. Such a formulation implies that renal adrenergic nerve activity is important to the regulation of glomerular AII receptors by indirect mechanisms and that the most likely intermediary link is the receptor regulatory response to changes in local intrarenal AII generation rate and/or concentration. If this formulation is correct, then certain other sympatholytic drugs utilized in the 
treatment of hypertension which decrease intrarenal AII generation may also result in increases in glomerular AII receptors.

In summary: ( $a$ ) Subacute unilateral renal denervation results in renal vasodilation in conditions of plasma volume expansion. This renal vasodilation observed both at the whole kidney and single nephron level appears to be, in large part, a consequence of decreased AR. These data add to the concept that AR is maintained in part by the renal adrenergic activity. (b) Unilateral renal denervation (4-6 d) magnifies the effect of exogenous AII infusion on glomerular dynamics. Specifically, renal denervation resulted in a greater elevation of $\Delta P$ through increased $P_{\mathrm{G}}$, increased ER, a greater reduction in nephron plasma and blood flow, and a lower value for the LpA in response to AII infusion compared with the normally innervated kidney. $(c)$ The increased vascular response to exogenous infusions of AII after denervation is associated with the observation that the $B_{\mathrm{MAX}}$ of glomerular AII receptors is increased 4-6 d after this procedure. The increase in AII receptors in glomeruli of denervated kidneys may have resulted from reductions in local renal AII concentration and/ or production as a consequence of the elimination of renal adrenergic activity.

\section{Acknowledgments}

The authors acknowledge the excellent technical assistance of Mr. Orjan Peterson and gratefully acknowledge the word processing of Ms. J. McCracken and Ms. D. Rinaldo.

These studies were supported by U.S. Public Health Service grants 3P50-HL-25457 (SCOR Hypertension) and AM-28602 and by the Veterans Administration.

\section{References}

1. Blantz, R. C., K. S. Konnen, and B. J. Tucker. 1976. Angiotensin II effects upon the glomerular microcirculation and ultrafiltration coefficient of the rat. J. Clin. Invest. 57:419-434.

2. Steiner, R. W., and R. C. Blantz. 1979. Acute reversal by saralasin of multiple intrarenal effects of angiotensin. Am. J. Physiol. 237:F386F391.

3. Baylis, C., and B. M. Brenner. 1978. Modulation by prostaglandin synthesis inhibitors of the action of exogenous angiotensin II on glomerular ultrafiltration in the rat. Circ. Res. 43:889-898.

4. Myers, B. D., W. M. Deen, and B. M. Brenner. 1975. Effects of norepinephrine and angiotensin II on the determinants of glomerular ultrafiltration and proximal fluid reabsorption in the rat. Circ. Res. 37: 101-110.

5. Ichikawa, I., J. F. Miele, and B. M. Brenner. 1979. Reversal of renal cortical actions of angiotensin II by verapamil and manganese. Kidney Int. 16:137-147.

6. Ploth, D. W., and L. G. Navar. 1979. Intrarenal effects of the renin-angiotensin system. Fed. Proc. 38:2280-2285.

7. Stern, M. D., P. D. Bowen, R. Parma, R. W. Osgood, R. L. Bowman, and J. H. Stein. 1979. Measurement of renal cortical and medullary blood flow by laser-Doppler spectroscopy in the rat. Am. J. Physiol. 236: F80-F87.

8. Vander, A. J. 1965. Effect of catecholamine and the renal nerves on renin secretion in anesthetized dogs. Am. J. Physiol. 209:659-662.

9. Bichet, D., and J. Marc-Aurele. 1982. Renal intracortical blood flow and renin secretion after denervation by 6-hydroxydopamine. Can. J. Physiol. Pharmacol. 60:184-192.

10. Thames, M. C. 1984. Renin release: reflex control and adrenergic mechanisms. J. Hypertens. 2(Suppl. 1):57-66.

11. Pelayo, J. C., M. G. Ziegler, and R. C. Blantz. 1984. Angiotensin
II in adrenergic-induced alterations in glomerular hemodynamics. $\mathrm{Am}$. J. Physiol. 247:F799-F807.

12. Pelayo, J. C., and R. C. Blantz. 1984. Analysis of renal denervation in the hydropenic rat: interactions with angiotensin II. Am. J. Physiol. 246:F87-F95.

13. Tucker, B. J., C. A. Mundy, and R. C. Blantz. 1985. Contribution of adrenergic activity to renal vascular tone in chronic salt depletion. Clin. Res. 33:590A. (Abstr.)

14. Schweitzer, G., and K. H. Gertz. 1979. Changes in hemodynamics and glomerular ultrafiltration in renal hypertension in rats. Kidney Int. 15:134-141.

15. Pelayo, J. C., M. G. Ziegler, P. A. Jose, and R. C. Blantz. 1983. Renal denervation in the rat: analysis of glomerular and proximal tubular function. Am. J. Physiol. 244:F70-F77.

16. Blantz, R. C., and B. J. Tucker. 1978. Measurements of glomerular dynamics. In Methods of Pharmacology, Renal Pharmacology. Vol. 4. M. Martinez-Maldonaldo, editor. Plenum Publishing Corp., New York. 141-163.

17. Tucker, B. J., and R. C. Blantz. 1977. Factors determining superficial nephron filtration in the mature, growing rat. Am. J. Physiol. 232:F97-F104.

18. Kreisberg, J. I. 1983. Contractile properties of the glomerular mesangium. Fed. Proc. 42:3053-3057.

19. Lowry, O. H., N. H. Rosenbrough, A. L. Farr, and R. J. Randall. 1951. Protein measurements with the Folin phenol reagent. J. Biol. Chem. 193:265-275.

20. Chen, F. M., and M. P. Printz. 1983. Chronic estrogen treatment reduces angiotensin II receptors in the anterior pituitary. Endocrinology. 113:1503-1510.

21. Douglas, J. C., G. Brown, and C. White. 1982. Influence of cations on kinetics of angiotensin II binding to adrenal, renal, and smooth muscle receptors. Hypertension. 4(Suppl. III):III-79-III-84.

22. Blanc, E., J. Sraer, J. D. Sraer, L. Baud, and R. Ardaillou. 1978. $\mathrm{Ca}^{2+}$ and $\mathrm{Mg}^{2+}$ dependence of angiotensin II binding to isolated rat renal glomeruli. Biochem. Pharmacol. 27:517-524.

23. Intaglietta, M., R. F. Pawula, and W. R. Tompkins. 1970. Pressure measurements in mammalian vasculature. Microvasc. Res. 2:212-220.

24. Brenner, B. M., K. H. Falchuk, R. I. Keimowitz, and R. W. Berliner. 1969. The relationship between peritubular capillary protein concentration and fluid reabsorption by the proximal tubule. J. Clin. Invest. 48:1519-1531.

25. Landis, E. M., and J. R. Pappenheimer. 1963. Exchange of substances through capillary walls. In Circulation, Section 2. Vol. 2. W. F. Hamilton and P. Daw, editors. American Physiological Society, Washington, DC. 961-1034.

26. Durret, L. R., and M. G. Ziegler. 1980. A sensitive radioenzymatic assay for catechol drugs. J. Neurosci. Res. 5:587-598.

27. Tucker, B. J., O. W. Peterson, M. G. Ziegler, and R. C. Blantz. 1982. Analysis of adrenergic effects of the anesthetics Inactin and $\alpha$-chloralase. Am. J. Physiol. 243:F253-F259.

28. Blantz, R. C. 1974. Effect of mannitol upon glomerular ultrafiltration in the hydropenic rat. J. Clin. Invest. 54:1135-1143.

29. Bliss, C. I. 1967. Statistics in Biology. Vols. I and II. McGrawHill Book Co., New York.

30. Dunn, O. J., and V. A. Clark. 1974. Applied Statistics: Analysis of Variance and Regression. John Wiley \& Sons, New York. 221-304.

31. Rogenes, P. R., and C. W. Gottschalk. 1982. Renal function in conscious rats with chronic unilateral renal denervation. Am. J. Physiol. 242:F140-F148.

32. Smythe, C. M., J. F. Nickel, and S. E. Bradley. 1952. Effect of epinephrine, $l$-epinephrine, and $l$-norepinephrine and glomerular filtration rate, renal plasma flow, and the urinary excretion sodium, potassium and water in normal man. J. Clin. Invest. 31:499-506.

33. Zimmerman, B. G., F. M. Abboud, and J. W. Eckstein. 1964. Effects of norepinephrine and angiotensin on total and venous resistance in the kidney. Am. J. Physiol. 216:554-558.

34. Berl, T., W. L. Henrich, A. L. Erickson, and R. W. Schrier. 1979. 
Prostaglandins in the beta-adrenergic and baroreceptor secretion of renin. Am. J. Physiol. 236:F472-F477.

35. Reid, I. A., W. R. Schrier, and L. E. Earley. 1972. An effect of extrarenal beta-adrenergic stimulation in the release of renin. J. Clin. Invest. 51:1861-1869.

36. Taher, M. S., L. G. McLain, K. M. McDonald, and R. W. Schrier. 1976. Effect of beta-adrenergic blockade on renin response to renal nerve stimulation. J. Clin. Invest. 57:459-465.

37. Osborn, J., H. Holdaas, M. C. Thames, and G. F. DiBona. 1983. Renal adrenoceptor mediation of antinatriuretic and renin secretion responses to low frequency renal nerve stimulation in the dog. Circ. Res. 53:298-305.

38. Sraer, J., L. Baud, J.-P. Cosyns, P. Verroust, M.-P. Nivez, and R. Ardaillou. 1977. High affinity binding of ${ }^{125} \mathrm{I}$-angiotensin II to rat glomerular basement membranes. J. Clin. Invest. 59:69-81.
39. Skorecki, K. L., B. J. Ballermann, H. G. Rennke, and B. M. Brenner. 1983. Angiotensin II receptor regulation in isolated glomeruli. Fed. Proc. 42:3064-3070.

40. Ballermann, B. J., K. L. Skorecki, and B. M. Brenner. 1984. Reduced glomerular angiotensin II receptor density in early untreated diabetes mellitus in the rat. Am. J. Physiol. 247:F110-F116.

41. Hall, J. E., A. C. Guyton, T. E. Jackson, T. G. Coleman, T. E. Lohmier, and N. C. Trippodo. 1977. Control of glomerular filtration rate by renin-angiotensin system. Am. J. Physiol. 233:F366-F372.

42. Hall, J. E., A. C. Guyton, N. C. Trippodo, T. E. Lohmier, R. A. McCaa, and Q. W. Cowley. 1977. Intrarenal control of electrolyte exertion by angiotensin II. Am. J. Physiol. 232:F538-F544.

43. Edwards, R. M. 1983. Segmental effects of norepinephrine and angiotensin II on isolated renal microvessels. Am. J. Physiol. 244:F526F534. 